1995

\title{
Local Government Fiscal Burden in Nonmetropolitan America
}

Kenneth M. Johnson

Loyola University Chicago

John P. Pelissero

Loyola University Chicago, jpeliss@luc.edu

David B. Holian

Indiana University - Bloomington

Michael T. Maly

Loyola University Chicago

Follow this and additional works at: https://ecommons.luc.edu/politicalscience_facpubs

Part of the Political Science Commons

\section{Recommended Citation}

Johnson, Kenneth M., John P. Pelissero, David B. Holian, and Michael Maly, "Local Government Fiscal Burden in Nonmetropolitan America," Rural Sociology, 60 (3, 1995): 381-398

This Article is brought to you for free and open access by the Faculty Publications and Other Works by Department at Loyola eCommons. It has been accepted for inclusion in Political Science: Faculty Publications and Other Works by an authorized administrator of Loyola eCommons. For more information, please contact ecommons@luc.edu. (c) (1) $\Theta($

This work is licensed under a Creative Commons Attribution-Noncommercial-No Derivative Works 3.0 License. 


\title{
Local Government Fiscal Burden in Nonmetropolitan America ${ }^{1}$
}

\author{
Kenneth M. Johnson, John P. Pelissero,* \\ David B. Holian, ** and Michael T. Maly \\ Department of Sociology, *Department of Political Science, Loyola University of \\ Chicago, Chicago, Illinois 60626, and \\ **Department of Political Science, Indiana University, Bloomington, Indiana 47405
}

\begin{abstract}
Rising fiscal pressure on local governments in rural areas of the United States is documented in this study. The level of fiscal burden on taxpayers to support local governments in nonmetropolitan areas is found to be higher than that in metropolitan areas between 1977 and 1987. Using a model from the urban fiscal literature, the level of fiscal burden in nonmetropolitan areas is found to be influenced by a combination of demographic, socioeconomic, intergovernmental, and historical factors. Intergovernmental revenue transfers from the state and federal government play a critical role in determining the level of fiscal burden rural taxpayers bear. These findings have implications for rural economic development and for understanding how rural areas are influenced by the larger society.
\end{abstract}

\section{Introduction}

Local government plays a critical role in maintaining the quality of life in rural America by providing important services (e.g., education, public safety) and infrastructure (e.g., roads, sanitation, water supply). The quality of such services and infrastructure depends upon the capacity and willingness of the local population and economic base to generate revenues needed to accommodate spending demands. Local governments must balance their need for revenue with the capacity of taxpayers to support government budgets. If local government fiscal policies place too great a demand on taxpayers, the area can be said to have an excessive fiscal burden. Efforts to explain local economic development activities must be cognizant of this because too high a tax burden has the potential to dampen local economic development efforts and constrain future prospects (Cigler 1993; Reeder and Jansen 1995).

A principal concern of rural sociology is the linkage between rural areas and the larger society. Government represents an important conduit through which the influence of the larger society can be transmitted to rural areas. The growing integration of nonmetropolitan (nonmetro) areas into the national system has brought with it an increasingly complex web of intergovernmental relationships between local rural governments and the state and federal govern-

1 This research is supported by a grant from the National Research Initiative Competitive Grants Program, U.S. Department of Agriculture (grant no. 9237401-8283). 
ments. This web has provided additional resources to rural governments but has also placed constraints on them (Brown 1993). Delineating the impact this intergovernmental web has on rural governments contributes to understanding how extralocal forces influence rural America.

Government fiscal burden has been studied extensively at the state level (U.S. Advisory Commission on Intergovernmental Relations 1993) and among urban governments (e.g., Clark and Ferguson 1983, Ladd and Yinger 1989). This study differs from much previous research because it examines nonmetro areas. The wider incidence of fiscal burden set in place by all local governments within rural counties is examined rather than city-level fiscal stress. An integrated model of fiscal burden developed to examine urban fiscal burden (Morgan and England 1983) may have relevance in rural areas as well. Many of the factors influencing the level of fiscal burden in metropolitan (metro) areas are also present, often to a greater extent, in rural areas. This integrated model posits the level of fiscal burden in local government to be influenced by a variety of socioeconomic and demographic factors. This model is supplemented with additional variables measuring intergovernmental activities based on recent research by Reeder and Jansen (1995) and Brown (1993). The purpose is to provide a comprehensive, longitudinal examination of nonmetro fiscal burden in the United States.

\section{Review of previous research}

Defining and measuring local government fiscal burden has been challenging for social scientists (Bingham and Hawkins 1990). Government fiscal indicators that are adjusted for underlying socioeconomic conditions are considered to be the best measures of fiscal problems (Bingham and Hawkins 1990; Clark and Ferguson 1983; Ladd and Yinger 1989; Morgan and Pammer 1988; Sharp 1986). This is commonly measured by comparing changes in local government revenues to changes in local area wealth such as personal income.

Research on fiscal problems in local governments posits linkages between these and local demographic, socioeconomic, or intergovernmental conditions. Demographic factors influence the level of fiscal burden by impacting the ability of local governments to make public policies that provide and pay for services and infrastructure. Local revenue sources in areas with substantial population change are not likely to change as rapidly as the demand for services (Brown and Glasgow 1991). For example, counties with population loss usually must continue to raise revenues from a smaller base to adequately support local government programs because many government costs are fixed and thus difficult to cut in the short run 
(Reeder 1985). And, in nonmetro areas with population gain, the development of new infrastructure to accommodate anticipated growth often exceeds short-term revenues (Glasgow and Reeder 1990; Reeder 1985). Changes in the demographic composition of the local population also have direct and significant policy implications for government (Brown and Glasgow 1991). Nonmetro areas tend to include proportionally more older people and slightly more children than the nation as a whole but fewer young adults (Johnson 1993). Older adults and children require more government services and contribute less to the local economy than the working-age population (Mullins and Rosentraub 1992), making the funding of education and health care particularly difficult in such areas (Button 1992; South 1991). The cumulative impact of such demographic compositional shifts is reflected in the higher than average revenue burdens in nonmetro counties with a growing aging-in-place population (Reeder and Glasgow 1989).

Socioeconomic factors that have been found to be determinants of urban fiscal problems (Clark and Ferguson 1983; Morgan and England 1983) are likely to be influential in nonmetro areas as well. Previous research showed that higher levels of fiscal burden are particularly likely during periods of high unemployment, inflation, or recession and in low income areas (Brown and Deavers 1987). Nonmetro areas faced difficult economic times during most of the $1980 \mathrm{~s}$ after widespread economic gains during the 1970s (Elo and Beale 1988; Henry et al. 1986). These events are likely to have forced local governments to increase pressure on taxpayers in nonmetro areas.

Local fiscal conditions also are affected by changes in intergovernmental relations since the late 1970s: grants-in-aid from state and federal governments, the degree of centralization in state government financing of local services, and fragmentation of local government service assignments. Fiscal aid from the federal government peaked in 1978 and has declined ever since both as a share of state and local revenues and in real dollars (U.S. General Accounting Office 1992). These reductions affected many local governments, especially cities and counties, that relied heavily on intergovernmental aid to balance budgets, maintain services, and avoid increased debt (Benton 1986; Ebel 1991; Parker 1985). Elimination of general revenue sharing in 1987 also strained local budgets that had come to depend upon this relatively unrestricted form of aid (Downing 1991). The focus of federal aid programs also changed somewhat. From 1961 to 1990, intergovernmental revenues shifted away from capital investment for local areas and toward payments for individuals (U.S. General Accounting Office 1992). Intergovernmental transfers became an important source of revenue to rural governments during the past 30 years; reductions in such aid, particularly during the $1980 \mathrm{~s}$, appear to have had a significant impact 
(Cigler 1993). This is further evident in historically poor nonmetro counties where slow growth in government spending was found to be associated with limited growth in intergovernmental aid (Reeder and Jansen 1995). In addition, not only is most intergovernmental aid not well-targeted to needier communities (Pelissero and Morgan 1992; Stein and Hamm 1987) but most of the aid during the 1970s and $1980 \mathrm{~s}$ was formula-driven (U.S. General Accounting Office 1987; Wright 1982). This means that aid is awarded on the basis of a formula commonly measuring population size or number of pupils and offers no competitive advantage to governments preparing "better" grant proposals (Copeland and Meier 1984; Pelissero and Morgan 1992).

During the past two decades, both state and federal governments mandated that local governments provide many new services, often without supplying adequate new funding to pay for them. These unfunded mandates restrict local government options and increased revenue pressure on already hard-hit local taxpayers (Massey and Straussman 1985; Zimmerman 1987). In addition, significant variation exists among the states in the share of local services paid for by state governments. Such variation in the states' share of funding local services is a major cause of high local tax burden (Albritton and Brown 1986; Stonecash 1983) and it has worsened during the past 20 years. Finally, growth and fragmentation in the number of local governments, particularly special district governments (U.S. Bureau of the Census 1994), have contributed to the growing fiscal pressure at the local level (Nice 1983). All these factors may increase the likelihood of high levels of fiscal burden.

The literature points to the importance of several discrete factors-demographic, socioeconomic, and intergovernmental-in understanding the causes of fiscal burden. But separate models leave major components of fiscal burden unexplored. Combining the separate factors into an integrated model of fiscal burden (Morgan and England 1983) presents the best opportunity for comprehensive analysis of the determinants of fiscal burden at the local level.

\section{Research design}

Local government statutory responsibility for the delivery of services varies significantly from state to state. Under such circumstances, analysis of fiscal data for any specific unit of government captures a different proportion of total local government activity depending on the state and policy area. For example, primary and secondary education are county government responsibilities in some states, provided by numerous dependent school districts of city governments in other states, and by independent school districts in still others. In order to conduct this national study of local fiscal con- 
ditions and their causes, fiscal data for all local governments within a county were aggregated to the county level. This minimizes measurement error because 90 percent of local government service provision and revenue collection is confined to a single county, regardless of state. Examining all local government finances within a county is the only way to conduct the complete, cross-sectional national study necessary to examine the central research questions. This study includes the 2,333 U.S. counties in the 48 contiguous states that were nonmetro as of 1985 and for which complete data are available. ${ }^{2}$

The level of fiscal burden is operationalized as a barometer of fiscal pressure exerted on local citizens by all local governments in a county. Specifically, the dependent variable, fiscal burden, ${ }^{3}$ is calculated as own-source revenue of all local governments in a county divided by aggregate county income for each of three years-1977, 1982, and 1987 (see Clark and Ferguson 1983; Morgan and England 1983). ${ }^{4}$ A higher ratio of own-source revenue to aggregate income suggests more fiscal burden in a county. This ratio reflects the relationship between local residents' incomes and local governments' taxes and charges to support public services. This measure is preferred to one that is based upon the ratio of general revenue to aggregate income because general revenue includes money from intergovernmental sources. Of primary interest is how much local government revenue derives from own-source funds that must be supported by the local income base. Although governments in some counties may have opportunities to shift revenue sources from residents to tourists or have large extractive industries paying severance taxes (e.g., mines), in the aggregate the measure selected is expected to be an accurate operationalization of fiscal burden at the local level.

Counties are considered to have high levels of fiscal burden when own-source revenues consume at least 10 percent of the county's aggregate income in a given year. There is no universally accepted

\footnotetext{
${ }^{2}$ New England county equivalents are included as well as independent cities in Virginia and elsewhere.

${ }^{3}$ The term fiscal burden is intended to differentiate the dependent variable, which is a condition caused by government revenue policies and affecting taxpayers, from fiscal stress, a condition of a government derived from revenue and spending policies that indirectly affects local citizens. Fiscal stress is an appropriate label when studying a single level of local government (e.g., city or county), but when studying all local governments and their own-source revenue policies, the issue of government-created fiscal burden on taxpayers must be addressed. Finally, fiscal pressure or measures like the "representative tax system" are not appropriate to this study because each adjusts for local property values, an item not included in this study.

${ }^{4}$ Income data by county were not available for 1987; 1986 income data are used because that was the closest year available to the 1987 Census of Government finance data.
} 
criterion for specifying what is a high ratio of revenue to income. However, counties that demand more than 10 percent of the aggregate income of county residents to support local government generally are more than one standard deviation above the norm for all counties. Some previous research has considered a locality fiscally burdened if the ratio of revenue to aggregate income was more than one standard deviation above the mean for all similar localities (Reeder and Jansen 1995; Stinson 1968). The 10 percent threshold used here exceeds this criterion in each of the three years considered.

The model of fiscal burden has four major components, the first three of which (demographic, socioeconomic, intergovernmental) are derived from the integrated model of urban fiscal stress (Morgan and England 1983). Six independent variables measure demographic conditions. The first is population change, which will be measured as percent change in county population during the previous five years. Higher fiscal burden is expected in counties with greater population change. The local age structure represents a second demographic factor that may have a significant impact on the amount of fiscal burden in an area. Two variables are used to delineate the age structure in 1980: proportion of the population under age 20 and proportion of the population 65 and over. Both the young (particularly school age) and the elderly need more government services and put pressure on local budgets. A larger minority population also has been found to be associated with higher fiscal burden in the urban literature. The percentages of the population that are black and Hispanic will be used as predictors here. ${ }^{5}$ Population density also is included because research has suggested that providing government services to a sparsely settled population is more costly (Reeder and Jansen 1995).

Four variables measuring socioeconomic conditions are included. The structure of the local labor force is an important indicator of the local economic situation. Here the proportion of the labor force employed in manufacturing (expected to be inversely correlated with fiscal burden) and the percent employed in agriculture (expected to be positively associated with fiscal burden) are used as predictors. The unemployment rate for the county also will be used as a predictor, with higher unemployment anticipated to be related to greater fiscal burden. Finally, several dummy variables reflecting local socioeconomic conditions, such as persistent poverty, recreational amenities, and appeal as a retirement destination (Hady and Ross 1990; Johnson and Beale 1995), will be used to consider the impact of regional-based phenomenon influencing fiscal burden.

Data on percent Hispanic were unavailable for the 1977 cross-section; therefore, only the black percentage of the population is included in the analysis that year. 
Structural aspects of government and intergovernmental relations also are likely to influence fiscal burden. Of particular concern is the impact of intergovernmental dependency and the degree to which intergovernmental assistance is targeted to needier locales (Pelissero and Morgan 1992; Stein and Hamm 1987, 1994). Higher fiscal burden is expected if the proportion of general revenue from intergovernmental sources is smaller. Federal aid and state aid to local governments as a share of general revenue will be used as predictors. In states where fiscal centralization is high, a major portion of some services (e.g., education) is financed by state government. This is likely to reduce the level of fiscal burden on counties in that state. State centralization will be measured as the proportion of state-local general spending undertaken by the states. The degree of fragmentation of local governments within a rural county may increase fiscal burden, because greater numbers of governments can demand a bigger share of local taxes. For this reason, the number of local governments in a county is used as a control variable.

The final component added to the integrated model of fiscal burden is county fiscal history. Counties with a precedent for higher levels of fiscal burden are expected to experience continued fiscal burden in future years (Clark and Walter 1991). Therefore, fiscal burden history, a variable measuring the number of past periods of high fiscal burden, is used in the analyses. The 1987 variable is a trichotomy, coded 0 for no fiscal burden in 1982 and 1977, 1 for fiscal burden in either 1982 or 1977, and 2 for fiscal burden in both 1982 and 1977. The 1982 variable is a dichotomy coded 1 for the presence of 1977 fiscal burden and 0 for its absence.

Most of the data for this study are from the Census of Governments for 1977, 1982, and 1987 or from the U.S. decennial Census of Population and Housing for 1970 and 1980. Additional data are from the 1982 economic censuses, annual income estimates by the U.S. Bureau of the Census, and from the federal-state cooperative series that estimates county populations annually.

\section{Analysis}

Extent of fiscal burden

Although much scholarly attention has focused on metro fiscal problems, the extent of fiscal burden in nonmetro areas consistently exceeded that in metro areas between 1977 and 1987. This gap narrowed somewhat by 1987; but even that year the proportion of nonmetro counties with higher fiscal burden was 2.4 times greater than that in metro areas. High fiscal burden also has become more widespread in nonmetro counties. The percentage of such counties experiencing high fiscal burden increased from 9 percent in 1977 to nearly 15 percent in 1987; the gain was from 2 to 6 percent for 


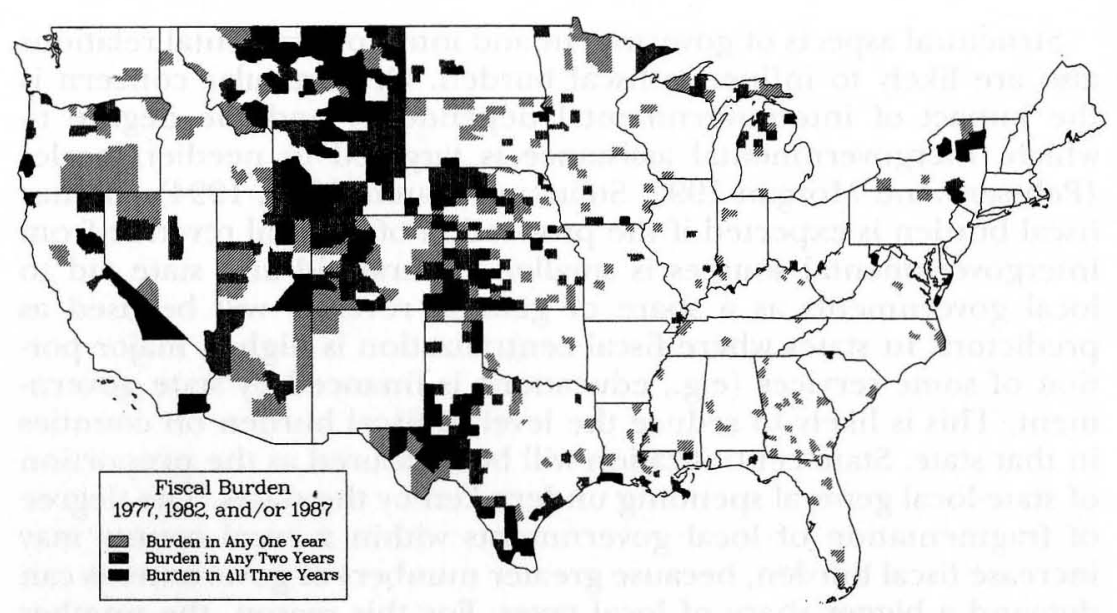

Figure 1. Nonmetropolitan fiscal burden, 1977, 1982 and 1987

metro counties. These findings underscore the substantial burden placed on local taxpayers by local government policymakers in some nonmetro areas as they attempted to support local programs and services from own-source revenues.

The difficulties in fulfilling local government service needs with own-source funds were particularly severe in counties with recurring high fiscal burden levels. Of 455 counties that experienced high levels of fiscal burden in one or more years, 51 percent had multiple occurrences of it. Many counties with only a single year of high fiscal burden experienced it for the first time in 1987, suggesting an increasing likelihood of high fiscal burden in the future if conditions do not improve or local officials do not implement fiscal austerity policies to reduce taxing. Fiscal burden problems are likely to be particularly severe in 117 counties $(5 \%$ of all nonmetro counties labeled chronic high fiscal burden counties) that experienced high levels of fiscal burden in each of the three years considered. Another six percent of counties had high fiscal burden in two time periods.

Pronounced spatial clustering is apparent in the geographic distribution of fiscal burden among nonmetro counties (Figure 1). Most counties experiencing high fiscal burden are proximate to other highly burdened counties. In addition, counties experiencing chronic high burden often cluster together forming a nucleus around which other burdened counties are grouped. Most counties with high fiscal burden are concentrated in the West, Great Plains, or west Texas counties. Other scattered pockets of high fiscal burden exist in the Upper Great Lakes and in New York. High fiscal burden is least common in the Southeast where dispersed counties experienced this condition for the first time in 1987. The incidence of 
high fiscal burden also appears to vary significantly by state, reinforcing earlier arguments that state government is an important actor in local government fiscal activity. Any concentration of heavily burdened counties will have significant policy implications for the affected areas and their states.

\section{Factors associated with rural fiscal burden}

Fiscal burden in nonmetro local governments is predicted to be affected by a number of interrelated factors. The first relationship of interest is that between population change and fiscal burden. As expected, this relationship is not linear. Comparing population change (1977-1982 and 1982-1987) to fiscal burden at the end of each period suggests a curvilinear association between the phenomena. Fiscal burden was greater in nonmetro counties with population change in excess of 10 percent in the previous five years. High fiscal burden was more likely among counties with substantial population decline but also occurred in counties with substantial growth. Fiscal burden was lowest among counties with slow population growth. This confirms earlier fragmentary evidence of a relationship between population change and fiscal burden, and supports arguments that there are costs associated with population growth as well as decline (Brown and Glasgow 1991; Glasgow and Reeder 1990; Reeder 1985).

Fiscal burden increased slightly as the proportion of the population under age 20 rose in 1987, though the relationship was not significant in earlier years (Table 1 ). In contrast, large concentrations of population over the age of 65 reduced the level of fiscal burden. The finding of slightly higher burdens in counties with large concentrations of young people is consistent with the expectation that they require more services from the government. However, higher levels of fiscal burden also would have been expected in areas with large elderly concentrations but this is not supported by the correlational analysis.

Higher levels of fiscal burden are evident in nonmetro areas with large Hispanic concentrations, but the extent of fiscal burden is lower in areas with larger concentrations of blacks. The finding for counties with higher black populations may be a function of the heavy concentration of blacks in the rural South, where high fiscal burden has been less common. These data also confirm that the level of fiscal burden was higher in counties containing fewer than six persons per square mile. Significant diseconomies of scale are involved in providing services such as highways and education to a sparsely settled population. The revenue base in such areas also is small. This finding helps to explain the spatial concentration of counties with high levels of fiscal burden in interior regions of the West and the Great Plains where population density is quite low. 
Table 1. Bivariate correlations between independent variables and fiscal burden, 1977, 1982, and 1987

\begin{tabular}{lccc}
\hline \multicolumn{1}{c}{ Variables } & \multicolumn{3}{c}{ Fiscal burden } \\
\cline { 2 - 4 } & 1987 & 1982 & 1977 \\
\hline Demographic & & & \\
Percent under age 20 & $0.09^{* *}$ & 0.02 & -0.00 \\
Percent age 65 and over & $-0.14^{* *}$ & $-0.06^{* *}$ & -0.02 \\
Percent Hispanic & $0.20^{* *}$ & $0.15^{* *}$ & - \\
Percent black & $-0.10^{* *}$ & $-0.18^{* *}$ & $-0.23^{* *}$ \\
Low-density counties & $0.29^{* *}$ & $0.35^{* *}$ & $0.43^{* *}$ \\
Socioeconomic & & & \\
Percent unemployed & 0.01 & $-0.24^{* *}$ & $-0.14^{* *}$ \\
Percent in manufacturing & $-0.31^{* *}$ & $-0.36^{* *}$ & $-0.42^{* *}$ \\
Percent in agriculture & $0.25^{* *}$ & $0.34^{* *}$ & $0.38^{* *}$ \\
Recreational counties & $0.10^{* *}$ & $0.07^{* *}$ & $0.08^{* *}$ \\
Poverty counties & $-0.13^{* *}$ & $-0.20^{* *}$ & $-0.21^{* *}$ \\
Retirement counties & $-0.10^{* *}$ & $-0.11^{* *}$ & $-0.13^{* *}$ \\
Government & & & \\
State centralization & $-0.19^{* *}$ & $-0.25^{* *}$ & $-0.27^{* *}$ \\
State intergovernmental revenue & $-0.62^{* *}$ & $-0.66^{* *}$ & $-0.66^{* *}$ \\
Federal intergovernmental revenue & $-0.10^{* *}$ & $-0.22^{* *}$ & $-0.28^{* *}$ \\
Number of governments & -0.01 & $0.05^{*}$ & $0.08^{* *}$ \\
Burden history & & & \\
Chronic high burden counties & $0.55^{* *}$ & $0.50^{* *}$ & - \\
Number of cases & 2,333 & 2,333 & 2,333 \\
\hline
\end{tabular}

* Significant at $0.05 ; * *$ significant at 0.01 .

Among the socioeconomic variables, areas with high concentrations of manufacturing employment tend to have less severe fiscal burden. This may result from higher incomes derived from manufacturing employment as well as from property tax contributions of local manufacturing establishments. In contrast, in areas where employment in agriculture and related extractive industries is high, so too is the level of fiscal burden. Fiscal problems in such areas may have been exacerbated by significant economic difficulties during the 1980 s due to the farm debt crisis, energy price fluctuations, and variations in the timber industry (Elo and Beale 1988). The unemployment rate in a county also is associated with the degree of fiscal burden, though in an unexpected direction. A negative relationship is evident between unemployment and fiscal burden in both 1977 and 1982, though no relationship is found between the variables in 1987. In the earlier periods fiscal burden levels are higher in areas with low levels of unemployment.

Recreational counties experienced more fiscal burden than might have been expected given their widespread economic and demographic gains during the 1970s and 1980s (Johnson 1993). The high 
ratio of revenue to income in such counties indicates that such counties supplement their taxbase with revenue from recreational activities (e.g., lodging and amusement taxes, sales taxes). However, such counties face greater costs for infrastructure (more highways, larger sewage and water systems) and personnel (more police officers, firefighters, paramedics) than would a nonrecreational county of the same size because of the large transient population (Johnson and Beale 1995). Any disruption to this recreational revenue stream has serious consequences for local governments in such counties.

The level of fiscal burden was low in retirement destination and persistent poverty counties. Although lower burdens were expected in retirement destination counties (Reeder and Glasgow 1989), the lack of high fiscal burden in persistent poverty counties is surprising. It appears to be uncommon in such counties because they spend little on local government and receive little revenue, thereby offsetting low aggregate incomes. Whether the low level of government services provided in persistent poverty counties is adequate is beyond the scope of this study but it has been considered elsewhere (Reeder and Jansen 1995).

Several structural aspects of government also were related to the level of fiscal burden in a county. State centralization measures the proportion of state-local general spending undertaken by the states. Increased state centralization diminished the likelihood of higher fiscal burden in each period. As expected, higher levels of fiscal burden occurred where the proportion of general revenue from intergovernmental sources was lower. The very high bivariate relationship between state intergovernmental revenue and fiscal burden underscores the critical role of state support in maintaining the fiscal condition of governments in rural counties. Greater federal intergovernmental transfers of revenue also reduce the level of fiscal burden but not to the same degree as the state contribution.

A history of chronic high fiscal burden also was expected to increase the likelihood that a county will continue to face this problem (Clark and Walter 1991). The data also support the expectation of a strong association between prior fiscal burden and later occurrences of it. This underscores the point that high levels of fiscal burden are a continuing rather than an intermittent problem.

\section{Multivariate analysis}

Bivariate analysis provides some indication of how the various independent variables are related to fiscal burden. Because of the complex interlinkages between these variables, multivariate analyses (Table 2) are necessary to delineate the full impact of the independent variables on the dependent variable.

The first block of variables introduced (model 1) in the multivariate model reflects the impact of demographic forces. Together they 
Table 2. Effects of background and intergovernmental variables on fiscal burden, 1987

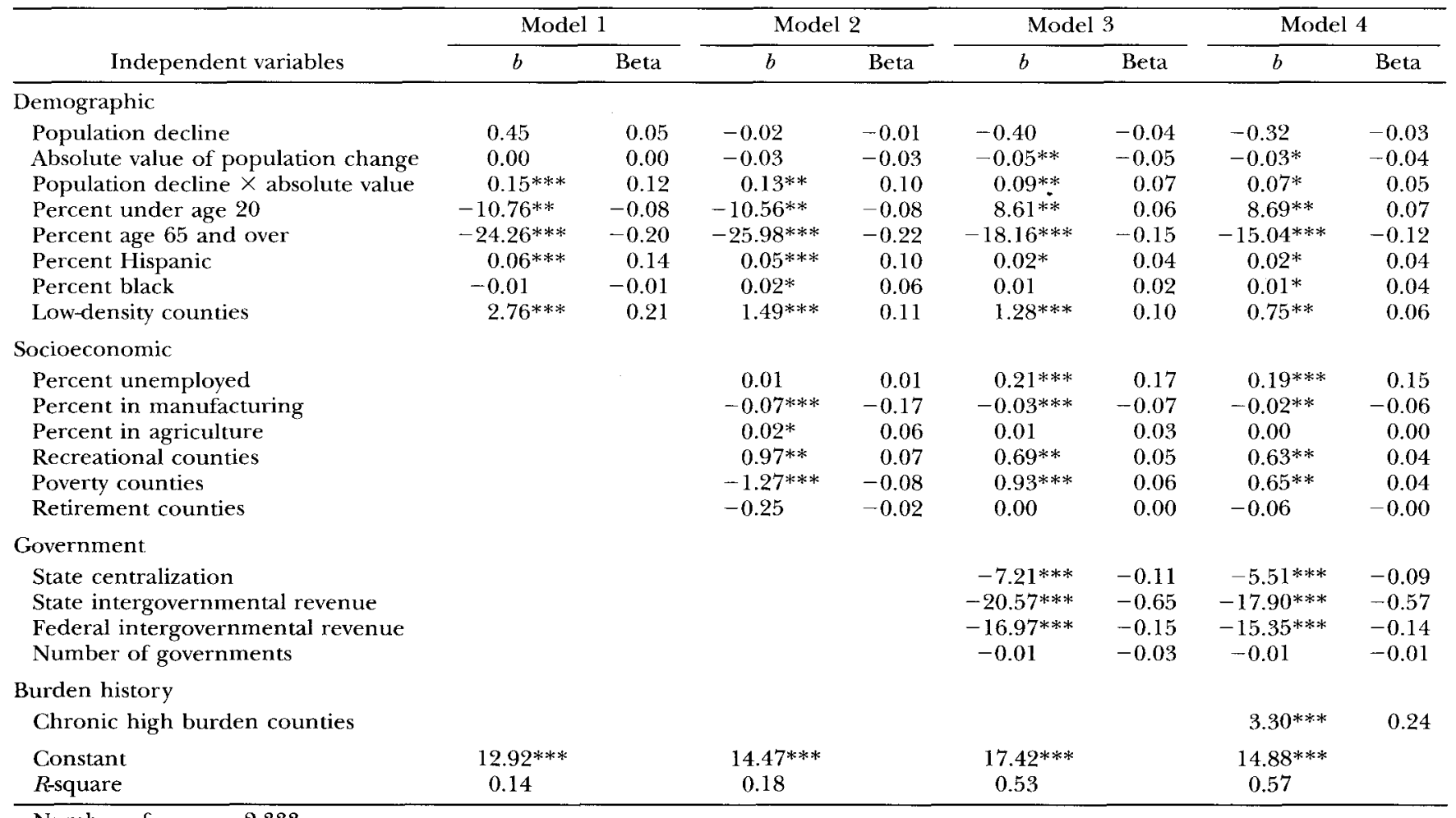

Number of cases $=2,333$.

* Significant at $0.05 ; *$ significant at $0.01 ; * * *$ significant at 0.001 . 
account for approximately 14 percent of the variance in fiscal burden in 1987. In this regard, the overall impact of population change is statistically significant, accounting for nearly four percent of the variance in burdens. ${ }^{6}$ The level of fiscal burden increases as the magnitude of population change increases. This acceleration is significantly more rapid in the face of population loss as opposed to population gain of the same magnitude. Other influential variables include the two representing age structure, both of which reduce the levels of fiscal burden when other variables are held constant, and percent Hispanic and low density, both of which increase the level of fiscal burden.

The addition of the socioeconomic variables (model 2) modestly increases the explanatory power of the model. The most influential variables are the percent of labor force in manufacturing and whether the county is one with persistent poverty. Both of these factors tend to reduce the levels of fiscal burden, when other factors remain constant.

Inclusion of variables related to intergovernmental relations (model 3) substantially increases the explanatory power. Greater state centralization and higher percentages of revenue from federal and state sources all are significantly associated with lower fiscal burden in 1987. The importance of state government as a source of intergovernmental funds is clearly evident in the large negative coefficient in the model. The variance explained in this model rises to 53 percent.

Adding the fiscal history variable (model 4) improves the predictive power of the model modestly. A history of chronic high fiscal burden increases the level of fiscal burden in 1987, if other variables remain constant. ${ }^{7}$

The regression models indicate that the level of fiscal burden in a nonmetro county is influenced by a number of factors and together they account for a substantial proportion of the variation in

\footnotetext{
${ }^{6}$ Because of the nonlinear relationship between population change and fiscal burden, population change is represented by three variables. The first variable (population decline) is a dummy coded 1 if population decline occurred between 1982 and 1987. The second variable (absolute value) measures the absolute percentage change in population between 1982 and 1987. The third variable is the interaction of the first two. Interpretation of the individual coefficients is not appropriate because it is only when the three components are used simultaneously that the full impact of population change is measured.

${ }^{7}$ Examination of diagnostics for multicollinearity including tolerance, variance inflation factors, eigen values, and condition indexes reveals no evidence of significant collinearity among the independent variables. The mean tolerance is 0.61 and the minimum is 0.33 . Moderate negative correlations do exist between some variable pairs such as percent under age 20 and percent 65 or older $(r=-0.67)$ or percent in manufacturing and percent in farming $(-0.66)$. This is expected given the nature of the variables. However, even in such cases there is no evidence of significant degradation in the estimated parameters.
} 
burden. What is less evident from the analysis is how these variables exert their influence. To highlight this, a path model was developed using only variables that exerted a significant influence on fiscal burden. ${ }^{8}$ These paths clarify several of the bivariate relationships that appear counter-intuitive.

For example, in the bivariate analysis, unemployment levels were not significantly correlated with fiscal burden in 1987. Yet, in the regression analysis, the extent of fiscal burden was significantly greater in areas with high unemployment when other variables were controlled. The explanation for this difference derives from the substantial negative indirect effect of unemployment rates on fiscal burden mediated through state intergovernmental revenues. Areas with higher unemploymẹnt tend to receive a larger proportion of their revenue from the state, which diminishes the degree of fiscal burden. Thus the substantial negative indirect effect offsets the positive effect. The relationship between poverty and fiscal burden is similar.

In contrast, areas with concentrations of older citizens not only have a negative direct effect on fiscal burden, they also tend to receive more intergovernmental revenues that, in turn, reduce fiscal burden. Although no causal direction can be ascertained, areas with large senior concentrations tend to have fewer children and lower unemployment, which further diminishes fiscal burden in the area. As the level of federal intergovernmental transfers increases, fiscal burden also diminishes, though the effect is much smaller than for state intergovernmental transfers. In addition, the influence of relatively few antecedent variables is mediated through federal intergovernmental transfers.

\section{Conclusion}

Modeling fiscal burden demonstrates the importance of an integrated model that encompasses theoretically important demographic, socioeconomic, and intergovernmental factors as well as fiscal history. Multivariate analysis underscores the complexity of the relationship between fiscal burden and theoretically important predictors. Demographic and socioeconomic factors exert a significant influence on the level of fiscal burden in rural counties. However, the most influential factor is intergovernmental assistance from states (and to a lesser extent the federal government) to local governments. If a state commits substantial resources to aid local governments, the extent of fiscal burden is substantially diminished because the state's influence is reflected both directly and indirectly. If other factors remain constant, increased intergovernmental revenue transfers from the state dramatically reduce the level of local fiscal burden. Although federal intergovernmental transfers also di-

\footnotetext{
${ }^{8}$ The path model and detailed multivariate analysis are available from the authors.
} 
minish fiscal burden levels, the impact is much more modest than for the state variable.

Several aspects of this research contribute to theoretical understanding of problems in nonmetro areas. First, it illustrates an important avenue through which the influence of the larger society affects future growth prospects and the quality of life in rural areas. In this regard, the complex web of intergovernmental relations, which provide resources but also impose mandates, influence rural people and institutions regardless of location. Second, the higher levels of fiscal burden in nonmetro counties when compared with metro counties are significant. This finding demonstrates that the fiscal difficulties of local government reach beyond the highly publicized problems of the big cities to encompass rural America as well. Therefore, the fiscal problems of rural governments must be considered in any policy initiatives to address local government finance. Third, the effectiveness of the integrated model in predicting higher fiscal burden is consistent with urban research (Morgan and England 1983). More than half of the variation in local fiscal burden is accounted for by such a model. Fourth, the key role of intergovernmental assistance in local fiscal affairs is underscored. Consistent with much of the intergovernmental aid targeting literature (Pelissero and Morgan 1992; Stein and Hamm 1987, 1994), state aid to local governments is a major factor influencing the degree of fiscal burden on rural governments. State aid gives local government more programmatic flexibility in using own-source revenues because they can shift the financing of some activities to state dollars. Without sufficient aid, local fiscal burden is high. States, therefore, remain key players in the fiscal health of rural communities.

These findings have practical implications for rural economic development policy as well. Rural governments struggling with high fiscal burden are likely to come under pressure to reduce revenue demands by cutting services and foregoing infrastructure improvements. Yet, poor services and an inferior infrastructure erode the quality of life and competitiveness of the local area. As a result, private investment and employment opportunities are likely to diminish, stimulating more young adults-who are the future human capital of the area- to leave. The resulting downward spiral increases the likelihood of high fiscal burden for these areas in the future.

In sum, this research provides a better understanding of the determinants of nonmetro fiscal conditions in the United States and provides important new information to researchers studying rural conditions and trends. It demonstrates that many of the same factors that cause greater urban fiscal burden also operate in rural areas. Finally, this study shows how the web of intergovernmental relationships mediates the influence of the larger society on economic conditions and the quality of life in even the most remote rural places. 


\section{References}

Albritton, Robert, and Robert D. Brown.

1986 "Intergovernmental impacts on policy variations within states: effects of local discretion on general assistance programs." Policy Studies Review 5:529-35.

Benton, J. Edwin

1986 "Federal aid cutbacks and state and local government spending policies." Pp. 15-34 in J. Benton and D. Morgan (eds.), Intergovernmental Relations and Public Policy. Westport, CT: Greenwood Press.

Bingham, Richard D., and Brett W. Hawkins

1990 "A test of political bias in scholars' preference for measuring fiscal strain." Urban Affairs Quarterly 25:515-23.

Brown, David L.

1993 "Is the rural-urban distinction still useful for understanding structure and change in developed societies?" Pp. 1-7 in D. Brown and L. Johnson (eds.), Population Change and the Future of Rural America: Conference Proceedings. Washington, DC: U.S. Department of Agriculture.

Brown, David L., and Kenneth Deavers

1987 "Rural change and economic policy agenda for the 1980s." Pp. 1-31 in Rural Economic Development in the 1980s. U.S. Department of Agriculture, Economic Research Service Report No. AGES870724. Washington, DC: U.S. Government Printing Office.

Brown, David L., and Nina J. Glasgow

1991 "Capacity building and rural government adaptation to population change." Pp. 194-208 in C. Flora and J. Christenson (eds.), Rural Policies for the 1990s. Boulder, CO: Westview Press.

Button, J. W.

1992 "A sign of generational conflict: the impact of Florida's aging voters on local school and tax referenda." Social Science Quarterly 73:786-97.

Cigler, Beverly A.

1993 "Meeting the growing challenges of rural local government." Rural Development Perspectives 9(1):35-9.

Clark, Cal, and B. Oliver Walter

1991 "Urban political cultures, financial stress, and city fiscal austerity strategies." Western Political Quarterly 44:676-97.

Clark, Terry Nichols, and Lorna C. Ferguson

1983 City Money: Political Processes, Fiscal Strain, and Retrenchment. New York: Columbia University Press.

Copeland, Gary W., and Kenneth J. Meier

1984 "Pass the biscuits, pappy: congressional decision-making and federal grants." American Politics Quarterly 12:3-21.

Downing, R. G.

1991 "Urban county fiscal stress: a survey of public officials' perceptions and government experiences." Urban Affairs Quarterly 27:314-25.

Ebel, Robert D.

1991 "A profile of county finances." Intergovernmental Perspective 17(Winter): 14-17.

Elo, Irma T., and Calvin L. Beale

1988 The decline in American counter-urbanization in the 1980s. Paper presented at the meeting of the Population Association of America, New Orleans.

Glasgow, Nina, and Richard J. Reeder

1990 "Economic and fiscal implications of nonmetropolitan retirement migration." Journal of Applied Gerontology 9:433-51.

Hady, T. F., and P. J. Ross.

1990 An Update: The Diverse Social and Economic Structure of Nonmetropolitan America. Washington, DC: U.S. Department of Agriculture. 
Henry, Mark, Mark Drabenstott, and Lynn Gibson

1986 "A changing rural America." Economic Review 71:23-41.

Johnson, Kenneth M.

1993 "Demographic change in nonmetropolitan America." Rural Sociology 58: $347-65$.

Johnson, Kenneth M., and Calvin L. Beale.

1995 Nonmetropolitan recreational counties: identification and fiscal concerns. Demographic Change and Fiscal Stress Project Working Papers. Chicago: Loyola University.

Ladd, Helen F., and John Yinger

1989 America's Ailing Cities: Fiscal Health and the Design of Urban Policy. Baltimore: Johns Hopkins University Press.

Massey, Jane, and Jeffrey D. Straussmann

1985 "Another look at the mandate issue: are conditions-of-aid really so burdensome?" Public Administration Review 45:292-300.

Morgan, David R., and Robert E. England

1983 "Explaining fiscal stress among large U.S. cities: toward an integrative model." Policy Studies Review 3:73-8.

Morgan, David R., and William T. Pammer, Jr.

1988 "Coping with fiscal stress: predicting the use of financial management practices among U.S. cities." Urban Affairs Quarterly 24:69-86.

Mullins, Daniel R., and Mark S. Rosentraub.

1992 "Fiscal pressure? The impact of elder recruitment on local expenditures." Urban Affairs Quarterly 28:337-54.

Nice, David C.

1983 "An intergovernmental perspective on urban fragmentation." Social Science Quarterly 64:111-18.

Parker, R. Andrew

1985 "Matching federal spending to need: an urban policy scorecard 1977-83." Policy Studies Review 13:625-33.

Pelissero, John P., and David R. Morgan

1992 "Targeting intergovernmental aid to local schools: an analysis of federal and state efforts." Western Political Quarterly 45:985-99.

Reeder, Richard J.

1985 Rural Governments: Raising Revenues and Feeling the Pressure. Economic Research Service. Washington, DC: U.S. Department of Agriculture.

Reeder, Richard J., and Nina L. Glasgow

1989 The economic development consequences of growing elderly populations in nonmetro counties. Paper presented at the meeting of the Southern Regional Science Association, Chapel Hill, NC.

Reeder, Richard J., and Anicca A. Jansen

1995 Rural Government-Poor Counties 1962-1987. Washington, DC: U.S. Department of Agriculture.

Sharp, Elaine B.

1986 "The politics and economics of the new city debt." American Political Science Review 80:1271-88.

South, S. J.

1991 "Age structure and public expenditures on children." Social Science Quarterly 72:661-75.

Stein, Robert M., and Keith E. Hamm

1987 "A comparative analysis of the targeting capacity of state and federal intergovernmental aid allocations: 1977, 1982." Social Science Quarterly 68:447-65.

1994 "Explaining state aid allocations: targeting within universalism." Social Science Quarterly 75:524-40. 
Stinson, Thomas F.

1968 "Drawing a poverty line for government services: an initial attempt." American Journal of Agricultural Economics 50:1416-21.

Stonecash, Jeffrey

1983 "Fiscal centralization in American states: increasing similarity and persisting diversity." Publius 13:123-37.

U.S. Advisory Commission on Intergovernmental Relations

1993 Significant Features of Fiscal Federalism (vol. 2): Revenues and Expenditures. Washington, DC: U.S. Advisory Commission on Intergovernmental Relations.

U.S. Bureau of the Census

1994 Government Organization. 1992 Census of Governments, GC92(1)-1. Washington, DC: U.S. Government Printing Office.

U.S. General Accounting Office

1987 Grant Formulas: A Catalog of Federal Aid to States and Localities. Washington, DC: General Accounting Office.

1992 Intergovernmental Relations: Changing Patterns in State-Local Finances.

Wright, Deil S. Washington, DC: General Accounting Office.

1982 Understanding Intergovernmental Relations (2nd ed.). Monterey, CA: Brooks/Cole Publishing.

Zimmerman, Joseph F.

1987 "The state mandate problem." State and Local Government Review 19: $78-84$. 